\title{
Effect of feeding of blend of essential oils on methane production, growth, and nutrient utilization in growing buffaloes
}

\author{
M. A. Yatoo ${ }^{1,2}$, L. C. Chaudhary ${ }^{1, *}$, N. Agarwal ${ }^{1}$, V. B. Chaturvedi ${ }^{1}$, and D. N. Kamra ${ }^{1}$
}

* Corresponding Author: L. C. Chaudhary Tel: +91-581-2301318, Fax: +91-581-2303284,

E-mail: Icchaudhary1@rediffmail.com

${ }^{1}$ Rumen Microbiology Section, Centre of Advanced Faculty Training in Animal Nutrition, Indian Veterinary Research Institute Izatnagar, UP 243122, India ${ }_{2}^{2}$ Animal Nutrition Scientist, KVK- Budgam SKUASTKashmir 194302, India

ORCID

M. A. Yatoo

https://orcid.org/0000-0002-0775-9728 L. C. Chaudhary

https://orcid.org/0000-0002-6927-2931

N. Agarwal

https://orcid.org/0000-0002-0483-055X

V. B. Chaturvedi

https://orcid.org/0000-0003-3876-6776

D. N. Kamra

https://orcid.org/0000-0001-6257-0947

Submitted Jul 1, 2016; Revised Sept 19, 2016; Accepted Feb 15, 2017
Objective: An experiment was conducted to study the effect of a blend of essential oils (BEO) on enteric methane emission and growth performance of buffaloes (Bubalus bubalis).

Methods: Twenty one growing male buffaloes (average body weight of $279 \pm 9.3 \mathrm{~kg}$ ) were divided in to three groups. The animals of all the three groups were fed on a ration consisting of wheat straw and concentrate mixture targeting $500 \mathrm{~g}$ daily live weight gain. The three dietary groups were; Group 1, control without additive; Group 2 and 3, supplemented with $\mathrm{BEO}$ at 0.15 and $0.30 \mathrm{~mL} / \mathrm{kg}$ of dry matter intake (DMI), respectively.

Results: During six months feeding trial, the intake and digestibility of dry matter and nutrients (organic matter, crude protein, ether extract, neutral detergent fibre, and acid detergent fibre) were similar in all the groups. The average body weight gain was tended to improve $(\mathrm{p}=0.084)$ in Group 2 and Group 3 as compared to control animals. Feeding of BEO did not affect feed conversion efficiency of the animals. The calves of all the three groups were in positive nitrogen balance with no difference in nitrogen metabolism. During respiration chamber studies the methane production $(\mathrm{L} / \mathrm{kg} \mathrm{DMI}$ and $\mathrm{L} / \mathrm{kg}$ digestible dry matter intake was significantly $(\mathrm{p}<0.001)$ lower in Group 2 and Group 3 as compared to control animals.

Conclusion: The results indicated that the BEO tested in the present study have shown potential to reduce enteric methane production without compromising the nutrient utilization and animal performance and could be further explored for its use as feed additive to mitigate enteric methane production in livestock.

Keywords: Essential Oils; Methane; Plant Secondary Metabolites; Buffalo; Growth

\section{INTRODUCTION}

Economical and eco-friendly livestock production is a challenging task for the animal scientists because livestock sector suffers with great economic losses due to enteric methane production and environment gets polluted with the methane which is one of the important green house gases [1-4]. Use of plant origin feed additives to mitigate methane emission and to improve the performance of the animals is now been considered as desirable replacement of other feed additives like chemical, antibiotics, nitrate etc because of less risk of toxicity in the animal and no residual effect in animal produce [5-10]. The use of plant origin additives containing plant secondary metabolites (PSM) have preference in animal feeding because of their natural occurrence [11-13]. The most commonly tested PSMs are tannins, saponins and essential oils (EOs). Lots of work has been done using EOs as feed additive for rumen manipulation and the results are encouraging in terms of inhibition in methane production during feed fermentation in the rumen [14-18]. However, methane reduction is generally associated with adverse effect on feed digestibility $[19,20]$. There are limited feeding trials with EOs as feed additive and the results are contradictory in terms of enteric methane in- 
hibition and animal performance [21,22]. Therefore, present study was conducted to explore the possibility of using a blend of essential oils (BEO) on enteric methane inhibition and performance of buffalo calves. The EOs were tested in author's laboratory and the EOs exhibited antimethanogenic activity were selected for the preparation of BEO $[20,23]$. The blend was prepared to reduce individual oil level so that the adverse effect on feed digestibility could be diluted to achieve the maximum beneficial effects.

\section{MATERIAL AND METHODS}

\section{Experimental animals, feeding and sampling}

Twenty one growing male buffalo (Bubalus bubalis) calves of 9 to 11 months of age with average body weight of $198.5 \pm 4.98$ $\mathrm{kg}$ were divided in three groups and were fed as per [24] for six months. The three dietary groups were as control without additive (Group 1), Group 2, and 3 where the animals were fed on diet supplemented with a blend of BEO at 0.15 and 0.30 $\mathrm{mL} / \mathrm{kg}$ of dry matter intake (DMI), respectively. The three EOs viz., ajwain oil, garlic oil, and cinnamon leaf oil were purchased from Paras Perfumers, New Delhi and were mixed in equal proportion to make BEO. The animals were fed on wheat straw and concentrate mixture targeting $500 \mathrm{~g}$ daily weight gain. The additive was mixed well with the concentrate mixture before offering to the buffaloes and wheat straw was offered after the concentrate mixture was completely consumed by the animals. The growth performance was assessed by fortnight weighing of individual animals for two consecutive days and the change in body weight was recorded.

\section{Estimation of methane production in buffaloes}

Methane production was determined in an open circuit respiration chamber maintained at $25^{\circ} \mathrm{C}$ and $65 \%$ relative humidity. The animals were shifted in the chambers and after two days of acclimatization, methane was measured for two consecutive days. We have four chambers two for the acclimatization and two for measuring methane. Air flow rate of about 250 $\mathrm{L} /$ min was maintained and the amount of total volume of air passed through the chamber was measured. The concentration of methane of air going in and coming out of the chamber was measured by infrared methane analyzer (Analytical Development Co. Ltd, Hoddesdon, England, Model 300). The chamber was opened every $22 \mathrm{~h}$ to offer feed and to collect residues of feed and feces.

\section{Metabolism trial}

A metabolism trial of 9 days duration including 3 days adaptation followed by 6 days collection was conducted after 120 $\mathrm{d}$ of experimental feeding. All the animals were shifted in metabolic cages simultaneously as we have more than 30 metabolic cages in our animal sheds. The feed offered, residue, feces and urine were collected individually. Total feces and urine excreted in $24 \mathrm{~h}$ by the individual animal was collected quantitatively in labeled plastic bags. After mixing a suitable aliquot of fresh feces was taken for the dry matter (DM) estimation. Another aliquot of feces was taken in acidified sulfuric acid (25\%) for the estimation of nitrogen. The container for urine collection contained $20 \%$ sulphuric acid to protect the loss of ammonia. The appropriate aliquots of feed offered, residue left, feces and urine of 6 days collection was pooled animal wise and preserved for further analysis. The samples were analysed for DM (ID number 930.15), ash (ID number 942.05), organic matter $(\mathrm{OM})$, crude protein $(\mathrm{CP})(\mathrm{N} \times 6.25$, ID number 954.01), and ether extract (EE) (ID number 920.39) as per AOAC [25]. The neutral detergent fiber (NDFom) and acid detergent fiber (ADFom) content were analyzed as per Van Soest et al [26]. The NDFom was determined without amylase and expressed exclusive of residual ash.

\section{Statistical analysis}

The statistical analyses were performed as per standard methods by using SPSS computer package (SPSS version 17.0, SPSS Inc., Chicago, IL, USA) [27]. The data were statistically analyzed using factorial univariate analysis of variance. The treatment means were compared using Tukey's test. For all statistical analyses, probability values less than 0.05 were considered as significant.

\section{RESULTS}

\section{Chemical composition of feeds}

The ingredients and chemical composition of the concentrate mixture and wheat straw used for feeding of growing buffaloes is given in Table 1. The $\mathrm{CP}$ content of the concentrate mixture and wheat straw was $22.07 \mathrm{~g} / 100 \mathrm{~g}$ and $2.87 \mathrm{~g} / 100 \mathrm{~g}$, respectively.

Table 1. Chemical composition ( $/ \mathrm{kg}$ ) of concentrate mixture and wheat straw

\begin{tabular}{lcc}
\hline Ingredients & $\begin{array}{c}\text { Concentrate } \\
\text { mixture }\end{array}$ & $\begin{array}{c}\text { Wheat } \\
\text { straw }\end{array}$ \\
\hline Physical composition (g/kg fed basis) & 370 & - \\
Wheat bran & 300 & - \\
Maize & 300 & - \\
Deoiled soyabean meal & 20 & - \\
Mineral mixture & 10 & - \\
Salt & & \\
Chemical composition (g/kg dry matter basis) & 936 & 937 \\
Organic matter & 221 & 29 \\
Crude protein & 36 & 11 \\
Ether extract & 277 & 838 \\
Neutral detergent fiber expressed exclusive of & & \\
$\quad$ residual ash & 92 & 440 \\
Acid detergent fiber expressed exclusive of residual ash & 66 & 63 \\
Total ash & & \\
\hline
\end{tabular}


Table 2. Effect of feeding blend of essential oils (BEO) on body weight changes and feed conversion efficiency of growing buffalo calves

\begin{tabular}{|c|c|c|c|c|c|}
\hline Parameters & Group 1) & Group 2 & Group 3 & SEM & $p$ value \\
\hline Initial body weight (kg) & 198.4 & 198.9 & 199.3 & 4.981 & 0.999 \\
\hline Final body weight (kg) & 269.2 & 289.7 & 282.7 & 5.993 & 0.387 \\
\hline Net BW gain in 184 d (kg) & 70.73 & 90.80 & 83.86 & 3.790 & 0.084 \\
\hline Average daily gain $(\mathrm{g})$ & 384.4 & 493.5 & 455.7 & 20.60 & 0.084 \\
\hline Concentrate DM intake (kg/d) & 2.24 & 2.30 & 2.26 & 0.040 & 0.860 \\
\hline Wheat straw DM intake $(\mathrm{kg} / \mathrm{d})$ & 2.93 & 3.16 & 3.12 & 0.065 & 0.348 \\
\hline DM intake $(\mathrm{kg} / \mathrm{d})$ & 5.17 & 5.45 & 5.38 & 0.102 & 0.541 \\
\hline Total DM intake (kg) & 952 & 1003 & 988.9 & 18.83 & 0.542 \\
\hline Feed conversion ratio & 13.86 & 11.42 & 12.04 & 0.562 & 0.189 \\
\hline
\end{tabular}

SEM, standard error of the mean; DM, dry matter; BW, body weight; DMI, dry matter intake.

1) Group 1, control (without additive); Group 2, the rate of BEO at $0.15 \mathrm{~mL} / \mathrm{kg} \mathrm{DMl}$; Group 3, the rate of BEO at $0.30 \mathrm{~mL} / \mathrm{kg}$ DMI.

\section{Body weight gain, feed intake and feed conversion efficiency}

Effect of supplementation of BEO on body weight changes, DMI and feed conversion ratio is presented in Table 2. The average daily weight gain $(\mathrm{g} / \mathrm{d})$ tended to improve $(\mathrm{p}=0.084)$ in Group 2 and 3 compared to that of control animals. In six months, the animals of Group 2 and 3 gained 20 and $17 \mathrm{~kg}$ more weight than the control animals. The daily DMI was similar in all the three groups. The ratio of concentrate mixture and wheat straw in the diet was tried to maintain at 40:60 ratio but practically it came out to be $42: 58$ in the animals of all the three groups throughout the feeding trial. The feed conversion efficiency improved in EO supplemented groups as compared to control but the difference was non-significant $(\mathrm{p}>0.05)$.

\section{Nutrients digestibility and plane of nutrition}

There was no difference $(\mathrm{p}>0.05)$ in intake and digestibility coefficients of different nutrients (DM, OM, CP, EE, NDFom,

Table 3. Effect of feeding blend of essential oils (BEO) on plane of nutrition and apparentdigestibility of nutrients during metabolism trial in growing buffalo calves

\begin{tabular}{|c|c|c|c|c|c|}
\hline Parameters & Group $1^{1)}$ & Group 2 & Group3 & SEM & $p$ value \\
\hline Body weight $(\mathrm{kg})$ & 254.4 & 277.7 & 274.9 & 5.755 & 0.204 \\
\hline DM intake $\left(\mathrm{g} / \mathrm{kg} \mathrm{W}^{0.75}\right)$ & 83.03 & 83.73 & 84.32 & 0.823 & 0.843 \\
\hline CP intake (g/kg W. $\left.\mathrm{W}^{0.75}\right)$ & 9.43 & 9.26 & 9.31 & 0.060 & 0.512 \\
\hline DCP intake $\left(\mathrm{g} / \mathrm{kg} \mathrm{W} \mathrm{W}^{0.75}\right)$ & 6.47 & 6.17 & 6.15 & 0.110 & 0.448 \\
\hline \multicolumn{6}{|l|}{ Nutrients digestibility (\%) } \\
\hline Dry matter & 60.04 & 59.80 & 59.30 & 0.602 & 0.898 \\
\hline Organic matter & 62.17 & 61.81 & 60.95 & 0.811 & 0.847 \\
\hline Crude protein & 68.62 & 66.54 & 66.15 & 0.988 & 0.594 \\
\hline Ether extract & 76.16 & 75.26 & 74.99 & 1.538 & 0.958 \\
\hline Neutral detergent fibre & 52.68 & 50.02 & 49.24 & 0.950 & 0.330 \\
\hline Acid detergent fibre & 51.90 & 47.18 & 47.51 & 1.017 & 0.095 \\
\hline
\end{tabular}

SEM, standard error of the mean; $D M$, dry matter; $C P$, crude protein; $D C P$, digestible CP; DMI, dry matter intake.

1) Group1, control (without additive); Group 2, the rate of BEO at $0.15 \mathrm{~mL} / \mathrm{kg} \mathrm{DMl}$; Group 3, the rate of BEO at $0.30 \mathrm{~mL} / \mathrm{kg} \mathrm{DMI}$. and ADFom among groups (Table 3). During metabolic tri$\mathrm{al}$, the average body weights of the three groups were similar. The intake of $\mathrm{CP}$ and energy was also similar among the three groups indicating the animals of all the three groups during metabolic trial were in similar plane of nutrition.

\section{Nitrogen balance}

During the experimental period buffalo calves in all the three groups were in positive nitrogen balance (Table 4). Intake of nitrogen and output in feces and urine was similar in all the three groups. There was no difference in nitrogen retention, both as $\mathrm{g} / 100 \mathrm{~g}$ of nitrogen intake and as well as $\mathrm{g} / 100 \mathrm{~g}$ nitrogen absorbed in all the three groups.

\section{Methane emission and energy metabolism}

Effects of supplementation of BEO on DMI and methane emission during open circuit respiration calorimetry study are given in Table 5. The DMI was significantly higher in treatment groups $(\mathrm{p}<0.001)$ as compared to control during calorimetric study. Methane production in terms of $\mathrm{L} / \mathrm{d}$ was comparable among the three groups. The methane production in terms of $\mathrm{L} / \mathrm{kg}$ DMI and L/kg digestible dry matter intake (DDMI) was significantly lower $(\mathrm{p}<0.001)$ with 14.1 and 14.6 per cent reduction in group 2 and 14.2 and 13.8 per cent reduction in

Table 4. Effect of feeding blend of essential oils (BEO) on nitrogen intake and balance during metabolism trial in growing buffalo calves

\begin{tabular}{lccccc}
\hline Parameters & Group 1) & Group 2 & Group 3 & SEM & p value \\
\hline N intake $(\mathrm{g} / \mathrm{d})$ & 96.05 & 100.7 & 100.4 & 1.106 & 0.159 \\
Faecal N loss $(\mathrm{g} / \mathrm{d})$ & 30.12 & 33.74 & 33.96 & 1.133 & 0.327 \\
Urine N loss $(\mathrm{g} / \mathrm{d})$ & 45.24 & 43.90 & 40.83 & 1.213 & 0.345 \\
Total N loss $(\mathrm{g} / \mathrm{d})$ & 75.36 & 77.64 & 74.79 & 1.469 & 0.744 \\
N balance $(\mathrm{g} / \mathrm{d})$ & 20.69 & 23.10 & 25.56 & 1.426 & 0.417 \\
N retention \% of N intake & 21.54 & 22.99 & 25.40 & 1.359 & 0.607 \\
N retention \% of N absorbed & 31.53 & 34.23 & 38.28 & 1.821 & 0.549 \\
\hline
\end{tabular}

SEM, standard error of the mean; $\mathrm{N}$, nitrogen; DMI, dry matter intake.

1) Group1, control (without additive); Group 2, the rate of BEO at $0.15 \mathrm{~mL} / \mathrm{kg} \mathrm{DMl}$; Group 3, the rate of BEO at $0.30 \mathrm{~mL} / \mathrm{kg} \mathrm{DMI}$. 
Table 5. Effect of feeding blend of essential oils (BEO) on methane emission in growing buffalo calves

\begin{tabular}{lccccr}
\hline Parameters & Group 1 $^{1)}$ & Group 2 & Group3 & SEM & p value \\
\hline Body weight $(\mathrm{kg})$ & 257 & 277 & 278 & 9.747 & 0.095 \\
DM intake $(\mathrm{kg} / \mathrm{d})$ & $4.92^{\mathrm{a}}$ & $5.64^{\mathrm{b}}$ & $5.79^{\mathrm{b}}$ & 0.103 & $<0.001$ \\
$\mathrm{CH}_{4}(\mathrm{~L} / \mathrm{d})$ & 188.4 & 185.1 & 189.7 & 2.677 & 0.790 \\
$\mathrm{CH}_{4}(\mathrm{~L} / \mathrm{kg} \mathrm{DMI})$ & $38.32^{\mathrm{a}}$ & $32.90^{\mathrm{b}}$ & $32.73^{\mathrm{b}}$ & 0.641 & $<0.001$ \\
$\mathrm{CH}_{4}(\mathrm{~L} / \mathrm{kg} \mathrm{DDMI})$ & $64.10^{\mathrm{a}}$ & $55.01^{\mathrm{b}}$ & $55.23^{\mathrm{b}}$ & 1.21 & $<0.001$ \\
\hline
\end{tabular}

SEM, standard error of the mean; DM, dry matter; $\mathrm{CH}_{4}$, methane; DMI, dry matter intake.

1) Group1, control (without additive); Group 2, the rate of BEO at $0.15 \mathrm{~mL} / \mathrm{kg} \mathrm{DMl}$; Group 3, the rate of BEO at $0.30 \mathrm{~mL} / \mathrm{kg}$ DMI.

${ }^{\mathrm{ab}}$ Mean with different superscript within a row differ at $p<0.05$.

group 3 respectively as compared to control group.

\section{DISCUSSION}

The ration given to the animals was iso-nitrogenous and isoenergic. The $\mathrm{CP}$ content of the concentrate mixture and wheat straw were within range. The composition of all the nutrients matched the nutrient requirement profile of adult buffaloes for maintenance requirement [24]. Feeding of BEO did not affect the feed intake in any of the groups. No change in DMI by feeding of mixture of EOs in beef cattle and dairy cattle was also observed [28,15]. Similarly, However, Yang et al [29] observed 13 per cent improvement in feed intake by dietary supplementation of cinnamaldehyde. The difference in results obtained in different experiments conducted by various workers might be due to the difference in type, dose of EOs and also the type of diets given to the experimental animals.

There was no impact of BEO feeding on DMI and nutrients digestibility in buffalo calves. Beauchemin and McGinn [28] reported a lowered feed intake and digestibility of all the nutrients by feeding EOs in beef cattle. All the animals were in positive nitrogen balance with similar values indicating no effect of $\mathrm{BEO}$ feeding on nitrogen metabolism. The retention of $\mathrm{N}$ was not affected in lactating dairy cows [15] fed on diet supplemented with a mixture of EO compounds. Controlling microbial degradation of dietary $\mathrm{CP}$ in the rumen could effectively reduce $\mathrm{N}$ losses and improve efficiency of $\mathrm{N}$ utilization. However, decreased amino acids deamination in the rumen due to EOs feeding is one of the major findings resulting in steady supply of ammonia nitrogen for microbial protein production. The EOs might inhibit the hyper-ammonia producing bacteria (Clostridium sticklandii and Peptostreptococcus anaerobiosus) by suppressing the colonization and/or digestion of readily degradable substrates. But there is not consistency in the findings of different studies conducted by different workers.

The methane production (L/kg DMI, L/kg DDMI) was $14 \%$ lower in $\mathrm{BEO}$ treated groups as compared to control group. Patra et al [17] observed 23.5\% reduction in methane pro- duction in sheep with the use of combination of harad (rich in tannin) and garlic (rich in EOs). The feeding BEO in the present study inhibited methane emission without affecting feed digestibility. Normally the rate of $\mathrm{CH}_{4}$ production by ruminants depends on the level of feed intake. In the present study though DMI was significantly high in BEO supplemented groups but the methane production in terms of $\mathrm{L} / \mathrm{d}$ was not affected but when expressed as L/kg DMI it was significantly reduced. There was no reduction in methane production in beef cattle by feeding CRINA Ruminants neither on low nor medium quality diet [21]. The methane production increases almost linearly with feed intake, but methane emission/unit animal product must be reduced if an improvement in animal productivity is achieved. EOs can impair growth of fungi and viruses, and some ruminal protozoa attached with methanogens may be selectively affected [30]. Methane inhibiting activity of EOs might depend upon type of EO, concentration of active principals, dose of $\mathrm{EO}$ along with type of diet fed to experimental animals.

\section{CONCLUSION}

It is concluded that feeding of mixture of essential oils (BEO) reduced methane emission with improved live weight gain in buffaloes without affecting nutrient utilization. Therefore, the $\mathrm{BEO}$ tested in the present study seems to be a potential rumen modifier and needs to be verified on large number of animals.

\section{CONFLICT OF INTEREST}

We certify that there is no conflict of interest with any financial organization regarding the material discussed in the manuscript.

\section{ACKNOWLEDGMENTS}

The financial assistance provided to the first author in the form of a fellowship by the Director, ICAR- Indian Veterinary Research Institute, Izatnagar, and also research grant from ICAR, New Delhi India are gratefully acknowledged.

\section{REFERENCES}

1. Johnson DE, Hill TM, Ward GM, et al. Principle factors varying methane emissions from ruminants and other animals. In: Khalil MAK editor. Atmospheric methane: sources, sinks, and role in global change. NATO AD1 Series, 113. Berlin, Germany: Springer-Verlag; 1993.

2. Jayanegara A, Wina E, Takahashi J. Meta-analysis on methane mitigating properties of saponin-rich sources in the rumen: influence of addition levels and plant sources. Asian-Australas J Anim Sci 2014;27:1426-35. 
3. Perme B, Chaudhary LC, Agarwal N, Kamra DN. Effect of phyto additives and Saccharomyces cerevisiae on rumen fermentation and microbial profile in buffaloes. Indian J Anim Sci 2016;86:197-202.

4. Kim ET, Hwang HS, Lee SM, et al. Effects of medicinal herb extracts on in vitro ruminal methanogenesis, microbe diversity and fermentation system. Asian-Australas J Anim Sci 2016; 29:1280-6.

5. Benchaar C, Pomar C, Chiquette J. Evaluation of dietary strategies to reduce methane production in ruminants: a modelling approach. Can J Anim Sci 2001;8:563-74.

6. Beauchemin, KA, Kreuzer M, Mara FO, McAllister TA. Nutritional management for enteric methane abatement: a review. Aust J Exp Agric 2008;48:21-7.

8. Patra AK. Effects of supplementing low-quality roughages with tree foliages on digestibility, nitrogen utilization and rumen characteristics in sheep: a meta-analysis. Anim Physiol Anim Nutr 2010;94:338-53.

9. Kim ET, Kim CH, Min KS, Lee SS. Effects of plant extracts on microbial population, methane emission and ruminal fermentation characteristics in in vitro. Asian-Australas J Anim Sci 2012;25:806-11.

10. Samal L, Chaudhary LC, Agarwal N, Kamra DN. Effect of plants containing secondary metabolites as feed additives on rumen fermentation and rumen microbial profile of buffaloes. Anim Nutr Feed Technol 2015;15:427-37.

11. Kumar R, Kamra DN, Agarwal N, Chaudhary LC. In vitro methanogenesis and fermentation of feeds containing oil seed cakes with rumen liquor of buffaloes. Asian-Australas J Anim Sci 2007;20:1196-200.

12. Kumar R, Kamra DN, Agarwal N, Chaudhary LC. Effect of feeding a mixture of plants containing secondary metabolites and peppermint oil on rumen fermentation, microbial profile and nutrient utilization in buffaloes. Indian J Anim Sci 2011; 81:488-92.

13. Kim ET, Park CG, Lim DH, et al. Effects of coconut materials on in vitro ruminal methanogenesis and fermentation characteristics. Asian-Australas J Anim Sci 2014;27:1721-5.

14. Mitsumori M, Sun W. Control of rumen microbial fermentation for mitigating methane emissions from the rumen. Asian-Australas J Anim Sci 2008;21:144-54.

15. Benchaar C, Calsamiglia S, Chaves AV, et al. A review of plantderived essential oils in ruminant nutrition and production. Anim Feed Sci Technol 2008;145:209-28.

16. Agarwal N, Kamra DN, Chatterjee PN, Kumar R, Chaudhary LC. In vitro methanogenesis, microbial profile and fermentation of green forages with buffalo rumen liquor as influenced by 2 -bromoethanesulphonic acid. Asian-Australas J Anim
Sci 2008;21:818-23.

17. Patra AK, Kamra DN, Bhar R, Kumar R, Agarwal N. Effect of Terminalia chebula and Allium sativum on in vivo methane emission by sheep. Anim Physiol Anim Nut 2011;95:187-91.

18. Lin B, Wang JH, Lu Y, Liang Q, Liu JX. In vitro rumen fermentation and methane production are influenced by active components of essential oils combined with fumarate. Anim Physiol Anim Nutr 2013; 97:1-9.

19. Sakthivel PC, Kamra DN, Agarwal N, Chaudhary LC. Effect of sodium nitrate and nitrate reducing bacteria on in vitro methane production and fermentation with buffalo rumen liquor. Asian-Australas J Anim Sci 2012;25:812-7.

20. Pawar M, Kamra DN, Agarwal N, Chaudhary LC. Effects of essential oils on in vitro methanogenesis and fermentation of feed with buffalo rumen liquor. Agric Res 2014;3:67-74.

21. Tomkins NW, Denman SE, Pilajun R, et al. Manipulating rumen fermentation and methanogenesis using an essential oil and monensin in beef cattle fed tropical grass hay. Anim Feed Sci Technol 2015;200: 25-34.

22. Drong C, Meyer U, Von Soosten D, et al. Effect of monensin and essential oils on performance and energy metabolism of transition dairy cows. Anim Physiol Anim Nutr 2016;100:53751.

23. Samal L, Chaudhary LC, Agarwal N, Kamra DN. Impact of phytogenic feed additives on growth performance, nutrient digestion and methanogenesis in growing buffaloes. Anim Prod Sci 2016;56:472-81.

24. ICAR, Nutrients requirements for livestock and poultry. New Delhim, India: Indian Council of Agricultural Research; 1998.

25. AOAC. Official Methods of Analysis, 16th ed. Association of Official Analytical Chemists. Arlington, VA, USA: AOAC International; 1995.

26. Van Soest PJ, Robertson JB, Lewis BA. Methods for dietary fibre neutral detergent fibre and non-starch polysaccharide in relation to animal nutrition. J Dairy Sci 1991;74:3583-97.

27. SPSS. SPSS for Windows, Network version 11.5.1. Inc Chicago, IL, USA: SPSS; 2002.

28. Beauchemin KA, McGinn SM. Methane emissions from beef cattle: Effects of fumaric acid, essential oil, and canola oil. J Anim Sci 2006; 84:1489-96.

29. Yang WZ, Ametaj BN, He ML, Benchaar C, Beauchemin KA. Cinnamaldehyde in feedlot cattle diets: intake, growth performance, carcass characteristics, and blood metabolites. J Anim Sci 2010;88:1082-92.

30. Jouany JP, Morgavi DP. Use of 'natural' products as alternatives to antibiotic feed additives in ruminant production. Animal 2007;1: 1443-66. 